\title{
Involvement of Sphingosine 1-Phosphate in Nerve Growth Factor-Mediated Neuronal Survival and Differentiation
}

\author{
Lisa Cseh Edsall, Grisha G. Pirianov, and Sarah Spiegel \\ Department of Biochemistry and Molecular Biology, Georgetown University Medical Center, Washington, DC 20007
}

Sphingolipid metabolites, such as ceramide and sphingosine1-phosphate (SPP), are emerging as a new class of second messengers involved in cellular proliferation, differentiation, and apoptosis. Nerve growth factor (NGF), a neurotrophic factor for pheochromocytoma PC12 cells, induced a biphasic increase in the activity of sphingosine kinase, the enzyme that catalyzes the formation of SPP. This activation was blocked by K252a, an inhibitor of tyrosine kinase $A$ (trkA). A rapid 1.7-fold increase was followed by a marked prolonged increase reaching a maximum of fourfold to fivefold stimulation with a concomitant increase in SPP levels and a corresponding decrease in endogenous sphingosine levels. Levels of ceramide, the precursor of sphingosine, were only slightly decreased by NGF in serumcontaining medium. However, NGF decreased the elevation of ceramide induced by serum withdrawal. Treatment of PC12 cells with SPP did not induce neurite outgrowth or neurofilament expression, yet it enhanced neurofilament expression elicited by suboptimal doses of NGF. Moreover, SPP also protected PC12 cells from apoptosis induced by serum withdrawal. To further substantiate a role for SPP in the cytoprotective actions of NGF, we found that $N, N$-dimethylsphingosine, a competitive inhibitor of sphingosine kinase, also induced apoptosis and interfered with the survival effect of NGF. These effects were counteracted by exogenous SPP. Moreover, other structurally related compounds, such as dihydrosphingosine 1-phosphate and lysophosphatidic acid, had no significant protective effects. Our results suggest that activation of sphingosine kinase and subsequent formation of SPP may play an important role in the differentiation and survival effects induced by NGF.

Key words: NGF; sphingolipid metabolites; sphingosine 1-phosphate; apoptosis; neuronal differentiation; trkA; signal transduction
Sphingolipid metabolites are emerging as an important new class of lipid second messengers (Hannun, 1994; Kolesnick and Golde, 1994; Spiegel and Milstien, 1995). Several cytokines, including tumor necrosis factor $\alpha$ (TNF- $\alpha$ ), vitamin $\mathrm{D}_{3}$, $\gamma$-interferon, and interleukin 1, stimulate sphingomyelinase, leading to increased levels of ceramide. Ceramide, in turn, can arrest cell growth and induce differentiation and more recently has been implicated as a key component of programmed cell death, also known as apoptosis (Kolesnick and Golde, 1994; Hannun and Obeid, 1995). In contrast, further metabolites of ceramide, such as sphingosine produced from ceramide by ceramidase and sphingosine-1-phosphate (SPP) produced by sphingosine kinase-dependent phosphorylation of sphingosine, have been implicated as second messengers in the mitogenic actions of certain growth factors (Olivera and Spiegel, 1993). Thus, dissociation of growth factor-induced mitogenesis from cytokine-mediated apoptosis may be attributable to distinct sphingolipid-derived second messengers.

The role of sphingolipid metabolites in the regulation of neuronal survival, development, and death is now beginning to be appreciated (Riboni et al., 1995). Nerve growth factor (NGF) plays an important role in the survival and development of neurons in the central and peripheral nervous systems (Levi-Montalcini, 1987). The effects of NGF are predomi-

\footnotetext{
Received March 7, 1997; revised June 12, 1997; accepted June 27, 1997.

This work was supported by Research Grant 1RO1 CA61774 from the National Institutes of Health. We thank Dr. Gordon Guroff for helpful suggestions.

Correspondence should be addressed to Sarah Spiegel, Basic Science Building, Room 353, Georgetown University Medical Center, 3900 Reservoir Road, NW, Washington, DC 20007

Copyright (C) 1997 Society for Neuroscience $0270-6474 / 97 / 176952-09 \$ 05.00 / 0$
}

nantly mediated by tyrosine kinase A (trkA), the high-affinity NGF receptor that initiates complex signal transduction cascades, ultimately enhancing differentiation and promoting survival of neurons (Greene and Kaplan, 1995). The low-affinity neurotrophin receptor $\mathrm{p} 75^{\mathrm{NGFR}}$, a member of the tumor necrosis factor receptor superfamily, binds all NGF-related neurotrophins (Kaplan and Stephens, 1994; McDonald and Chao, 1995). The functional significance of $\mathrm{p} 75^{\mathrm{NGFR}}$ in signal transduction is still not completely understood, but it has been suggested to mediate apoptosis of developing neurons in the absence of trkA (Van der Zee et al., 1996). Recently, it has been demonstrated that NGF activates sphingomyelinase in rat T9 anaplastic glioblastoma cells through p $75^{\text {NGFR }}$ (Dobrowsky et al., 1994), indicating that ceramide may play a role in p $75^{\text {NGFR }}$ signaling. Interestingly, sphingomyelinase activation was diminished in cells coexpressing the $\mathrm{p} 75^{\mathrm{NGFR}}$ receptor and trkA but was reinstated when trkA function was blocked (Dobrowsky et al., 1995). This is in agreement with recent observations that the trkA receptor may negatively regulate the functional activity of p75 NGFR (Bothwell, 1996; Carter et al., 1996; Van der Zee et al., 1996). Because the relative balance of sphingolipid metabolites ceramide and SPP has recently been shown to influence opposing pathways of apoptosis and cell survival in HL-60 and U937 cells (Cuvillier et al., 1996), it was of interest to determine whether SPP production might play a role in the neurotrophic actions of NGF. For this purpose, we used rat pheochromocytoma PC12 cells that coexpress both $\mathrm{p} 75^{\mathrm{NGFR}}$ and trkA (Greene and Kaplan, 1995). Our results indicate that activation of sphingosine kinase and subsequent production of SPP may play an important biological 
role in cell survival signal transduction pathways activated by the binding of NGF to trkA.

\section{MATERIALS AND METHODS}

Materials. Mouse $2.5 \mathrm{~S}$ nerve growth factor was obtained from Upstate Biotechnology Inc. (Lake Placid, NY). Type I rat tail collagen was purchased from Collaborative Research (Lexington, MA). 12-OTetradecanoylphorbol-13-acetate (TPA), dihydrosphingosine, diethylenetriaminepentaacetic acid (DETPAC), monoclonal anti-neurofilament $\mathrm{M}$, essentially fatty acid-free bovine serum albumin (BSA), and bovine brain type IV ceramides were obtained from Sigma (St. Louis, MO). $O$-Phthalaldehyde was obtained from Aldrich (Milwaukee, WI). SPP, sphingosine, and $N, N$-dimethylsphingosine were purchased from Biomol Research Laboratory Inc. (Plymouth Meeting, PA). Lysophosphatidic acid and cardiolipin were purchased from Avanti Polar Lipids (Birmingham, AL). Dihydrosphingosine-1-phosphate was kindly provided by Dr. Alan P. Kozikowski (Georgetown University Institute for Cognitive and Computational Sciences). [methyl- $\left.{ }^{3} \mathrm{H}\right]$ Thymidine $(83 \mathrm{Ci} / \mathrm{mmol})$, $\left[\gamma_{-}{ }^{32} \mathrm{P}\right]$ ATP $(3000 \mathrm{Ci} / \mathrm{mmol})$, and $\left[{ }^{3} \mathrm{H}\right]$ acetic anhydride $(50 \mathrm{mCi} / \mathrm{mmol})$ were purchased from Amersham (Arlington Heights, IL). Serum and medium were obtained from Biofluids (Rockville, MD). Octyl- $\beta$-Dglucopyranoside and Escherichia coli diacylglycerol kinase were purchased from Calbiochem (La Jolla, CA).

Cell culture. Rat pheochromocytoma PC12 cells were kindly provided by Dr. Gordon Guroff (National Institute of Child Health and Human Development, National Institutes of Health, Bethesda, MD). Cells were maintained in RPMI medium supplemented with $10 \%$ heat-inactivated horse serum, $5 \%$ fetal bovine serum, $100 \mathrm{U} / \mathrm{ml}$ penicillin, and $100 \mu \mathrm{g} / \mathrm{ml}$ streptomycin (Batistatou and Greene, 1991). Cells were plated at a density of $5 \times 10^{4} / \mathrm{cm}^{2}$. In some experiments, cells were seeded onto plates coated with rat tail collagen $(50 \mu \mathrm{g} / \mathrm{ml})$.

Sphingosine kinase activity. After various treatments, cells were washed twice with PBS and harvested by scraping in buffer A $[0.1 \mathrm{M}$ Tris- $\mathrm{HCl}$, $\mathrm{pH} 7.4$, containing $20 \%$ (v/v) glycerol, $1 \mathrm{~mm}$ mercaptoethanol, $1 \mathrm{~mm}$ EDTA, $1 \mathrm{~mm} \mathrm{Na}_{3} \mathrm{VO}_{4}, 15 \mathrm{~mm} \mathrm{NaF}, 10 \mu \mathrm{g} / \mathrm{ml}$ leupeptin and aprotinin, 1 mM PMSF, and $0.5 \mathrm{~mm}$ 4-deoxypyridoxine]. Cells were lysed by freezethawing three times, and the cytosolic fraction was prepared by centrifugation at $13,000 \times g$ for $20 \mathrm{~min}$. Incubated together were $100 \mu \mathrm{l}$ of cytosolic fraction $(20-50 \mu \mathrm{g})$ with $10 \mu \mathrm{l}$ of sphingosine $(1 \mathrm{mM})$, delivered as a sphingosine-BSA complex ( $4 \mathrm{mg} / \mathrm{ml}$ BSA). Buffer A was added to a final volume of $190 \mu \mathrm{l}$, and reactions were started by addition of $10 \mu \mathrm{l}$ of $\left[\gamma^{-32}\right.$ P]ATP $(10-20 \mu \mathrm{Ci}, 20 \mathrm{~mm})$ containing $100 \mathrm{mM} \mathrm{MgCl}_{2}$. Samples were incubated for $30 \mathrm{~min}$ at $37^{\circ} \mathrm{C}$. Lipids were then extracted with chloroform/methanol/concentrated $\mathrm{HCl}(100: 200: 1, \mathrm{v} / \mathrm{v})$, and phases were separated as described previously (Olivera et al.,1994). Lipids from the organic phase were resolved by TLC on Silica Gel 60 plates using 1-butanol/methanol/acetic acid/water (80:20:10:20, v/v) as the solvent system. Labeled SPP was visualized by autoradiography, scraped from the plate, and counted with a scintillation counter.

Measurement of SPP. SPP levels were determined as described previously (Yatomi et al., 1995) with minor modifications. Briefly, after treatment with NGF for various times, cells were washed two times with $1 \mathrm{M}$ Tris- $\mathrm{HCl}, \mathrm{pH} 7.4$, harvested in $3.5 \mathrm{ml}$ of methanol/chloroform $/ 1 \mathrm{M}$ $\mathrm{KCl}(2: 1: 0.5, \mathrm{v} / \mathrm{v})$, and sonicated on ice. Alkaline extraction was performed by the addition of $4.1 \mathrm{ml}$ of chloroform $/ 1 \mathrm{M} \mathrm{KCl} /$ concentrated $\mathrm{NH}_{4} \mathrm{OH}(2: 2: 0.1, \mathrm{v} / \mathrm{v})$. The aqueous phase containing SPP was collected and re-extracted with $3.2 \mathrm{ml}$ of chloroform/concentrated $\mathrm{HCl}(3: 0.2, \mathrm{v} / \mathrm{v})$. Organic phases containing SPP were then evaporated under $\mathrm{N}_{2}$ and solubilized in $20 \mu \mathrm{l}$ of $0.008 \mathrm{~N} \mathrm{NaOH} /$ methanol and $20 \mu \mathrm{l}$ of $10 \mathrm{~mm}$ $\left[{ }^{3} \mathrm{H}\right]$ acetic anhydride $(10 \mu \mathrm{Ci})$. Acetylation reactions proceeded at $37^{\circ} \mathrm{C}$ for $2 \mathrm{hr}$. Acetylated SPP was extracted with $2.77 \mathrm{ml}$ of methanol/ chloroform $/ 1 \mathrm{M} \mathrm{KCl} /$ concentrated $\mathrm{HCl}$ (0.75:1:1:0.02, v/v). The chloroform phases were washed twice with $1 \mathrm{ml}$ of chloroform/methanol/water (3:48:47, v/v) and then evaporated under $\mathrm{N}_{2}$. Samples were dissolved in $200 \mu \mathrm{l}$ of chloroform/methanol (2:1, v/v) and applied to Silica Gel 60 TLC plates. After development with butanol/acetic acid/water (3:1:1, $\mathrm{v} / \mathrm{v}$ ), acetylated SPP was visualized by autoradiography using ${ }^{3} \mathrm{H}-$ enhancer spray (DuPont, Billerica, MA), scraped from the plates, and counted with a scintillation counter.

Measurement of sphingosine. Sphingosine levels were determined by an enzymatic method as described previously (Olivera et al., 1994) or by HPLC analysis (Wilson et al., 1988) with slight modifications. For both assays, after treatment with NGF cells were washed in $1 \mathrm{~m}$ Tris- $\mathrm{HCl}, \mathrm{pH}$ 7.4, and scraped in $0.5 \mathrm{ml}$ of methanol. Samples were extracted with chloroform/methanol/1 M KCl (1:0.5:1, v/v). For HPLC analysis, aliquots of the organic layer $(\sim 50-100 \mathrm{nmol}$ of total cellular phospholipid), containing dihydrosphingosine as an internal standard, were saponified by addition of $0.5 \mathrm{ml}$ of $0.1 \mathrm{~N} \mathrm{KOH} /$ methanol and incubation at $37^{\circ} \mathrm{C}$ for $60 \mathrm{~min}$. The reactions were terminated by the addition of $10 \mu \mathrm{l}$ of concentrated $\mathrm{HCl}$, and samples were extracted with $1 \mathrm{ml}$ of chloroform/1 $\mathrm{M} \mathrm{KCl}(1: 1, \mathrm{v} / \mathrm{v})$. Organic extracts were dried under $\mathrm{N}_{2}$, resuspended in $50 \mu \mathrm{l}$ methanol, and derivatized with $o$-phthalaldehyde for subsequent HPLC analysis (Wilson et al., 1988). Sphingosine and dihydrosphingosine were separated isocratically on a Cosmosil 5C18-AR column (4.6 $\times 250 \mathrm{~mm}$; Nacalai Tesque, Kyoto, Japan) using a Waters (Milford, MA) 600E pump with methanol/5 mM NaH $\mathrm{PO}_{4}, \mathrm{pH} 7.0$ (60:40, v/v), at a flow rate of $1 \mathrm{ml} / \mathrm{min}$. A Waters $420-\mathrm{AC}$ fluorescence detector was used to detect fluorescent derivatives with an excitation filter transmitting at a maximum of $340 \mathrm{~nm}$ and a cut-off emission filter at $400 \mathrm{nM}$. Sphingosine levels were quantified using the Rainin (Woburn, MA) Dynamax HPLC software package.

Measurement of ceramide. Lipids were extracted, and mass amounts of ceramide in cellular extracts were measured by the DAG kinase enzymatic method (Olivera and Spiegel, 1992). Briefly, an aliquot (10-50 nmol of total phospholipid) of the chloroform phase from cellular lipid extracts was dried under a nitrogen stream. The lipids or standard bovine brain type IV ceramides were resuspended in $40 \mu \mathrm{l}$ of $7.5 \%(\mathrm{w} / \mathrm{v})$ octyl- $\beta$-D-glucopyranoside $/ 5 \mathrm{~mm}$ cardiolipin in $1 \mathrm{~mm} \mathrm{DE}$ TPAC $/ 10 \mathrm{~mm}$ imidazole, $\mathrm{pH}$ 6.6, and solubilized by freeze-thawing and subsequent sonication. The enzymatic reaction was started by the addition of $20 \mu \mathrm{l}$ of DTT $(20 \mathrm{mM}), 10 \mu \mathrm{l}$ of $E$. coli diacylglycerol kinase $(0.88 \mathrm{U} / \mathrm{ml}), 20 \mu \mathrm{l}$ of $\left[\gamma^{-}{ }^{32} \mathrm{P}\right] \mathrm{ATP}(10-20 \mu \mathrm{Ci}, 10 \mathrm{mM})$, and $100 \mu \mathrm{l}$ of reaction buffer (in mM: 100 imidazole, $\mathrm{pH} 6.6,100 \mathrm{NaCl}, 25 \mathrm{MgCl}_{2}$, and 2 EGTA). After incubation for $1 \mathrm{hr}$ at room temperature, lipids were extracted with $1 \mathrm{ml}$ of chloroform/methanol/concentrated $\mathrm{HCl}$ $(100: 200: 1, \mathrm{v} / \mathrm{v})$ and $0.17 \mathrm{ml}$ of $1 \mathrm{M} \mathrm{KCl}$. Labeled phosphatidic acid and ceramide-1-phosphate were resolved by TLC with chloroform/acetone/ methanol/acetic acid/water (10:4:3:2:1, v/v). Bands corresponding to ceramide were scraped from the plates and counted with a scintillation counter or, alternatively, quantified with a Molecular Dynamics (Sunnyvale, CA) Storm PhosphorImager.

Measurement of total cellular phospholipids. Total phospholipids present in cellular lipid extracts used for sphingolipid analysis were quantified as described previously (Van Veldhoven and Mannaerts, 1987) with minor modifications. Briefly, to dried aliquots of cellular lipid extracts, $40 \mu \mathrm{l}$ of a mixture of $10 \mathrm{~N} \mathrm{H}_{2} \mathrm{SO}_{4} / 70 \%$ perchloric acid $(3: 1, \mathrm{v} / \mathrm{v})$ was added, and samples were incubated for $30 \mathrm{~min}$ at $210^{\circ} \mathrm{C}$. After cooling, $75 \mu \mathrm{l}$ of water and $400 \mu \mathrm{l}$ of $4.2 \%$ ammonium molybdate in $4 \mathrm{~N} \mathrm{HCl} / 0.045 \%(\mathrm{w} / \mathrm{v})$ malachite green $(1: 3 \mathrm{v} / \mathrm{v})$ was added. Samples were incubated at $37^{\circ} \mathrm{C}$ for $15 \mathrm{~min}$, and absorbances were measured at $660 \mathrm{~nm}$.

Quantitation of DNA fragmentation. DNA fragmentation was determined in cells prelabeled with $\left[{ }^{3} \mathrm{H}\right]$ thymidine $(1 \mu \mathrm{Ci} / \mathrm{ml})$ for $24 \mathrm{hr}$ (Duke and Cohen, 1992). Cells were washed gently twice with serum-free medium and then incubated in the same medium with the indicated agents for $4-24 \mathrm{hr}$ at $37^{\circ} \mathrm{C}$. Cells were harvested, lysed in TTE $(10 \mathrm{~mm}$ Tris, $\mathrm{pH}$ 7.4, $10 \mathrm{~mm}$ EDTA, and 0.2\% Triton X-100), and fragmented DNA was separated from intact chromatin by centrifugation. Pellets were suspended in TTE, and TCA was added to a final concentration of $12.5 \%$. $\left[{ }^{3} \mathrm{H}\right]$ Thymidine incorporated into both intact and fragmented DNA was determined by liquid scintillation counting (Duke and Cohen, 1992). Percent fragmented DNA $=100 \times($ fragmented $/($ fragmented + intact chromatin)).

Staining of apoptotic nuclei. Cells were cultured in serum-free medium in the absence or presence of the indicated agents for $24 \mathrm{hr}$, washed in PBS, and fixed in $3.7 \%$ formaldehyde for $10 \mathrm{~min}$. After washing with PBS, fixed cells were then incubated with bisbenzimide trihydrochloride (24 $\mu \mathrm{g} / \mathrm{ml}$ in 30\% glycerol/PBS; Hoechst 33258, Calbiochem) for $10 \mathrm{~min}$. Cells were then examined with a Zeiss (Petersburg, VA) Photoscope II fluorescent microscope. At a minimum, 500 cells were scored. Apoptotic cells were distinguished by condensed, fragmented nuclear regions.

Determination of cell survival. Intact nuclei were determined as described previously (Batistatou and Greene, 1991). Briefly, PC12 cells cultured in 24-well collagen-coated plates were treated for $24 \mathrm{hr}$ with various agents in serum-free medium. Medium was then aspirated, and cells were lysed in $200 \mu \mathrm{l}$ of $10 \% \mathrm{Z}$ apoglobin (Fisher Scientific, Houston, $\mathrm{TX}$ ) in $0.5 \times \mathrm{PBS}$ containing $0.5 \%$ Triton X-100, $2 \mathrm{~mm} \mathrm{MgCl}_{2}$, and 15 $\mathrm{mm} \mathrm{NaCl}$. This solution provides a uniform suspension of nuclei, which were counted with a hemocytometer. Four separate fields were counted for each sample. 


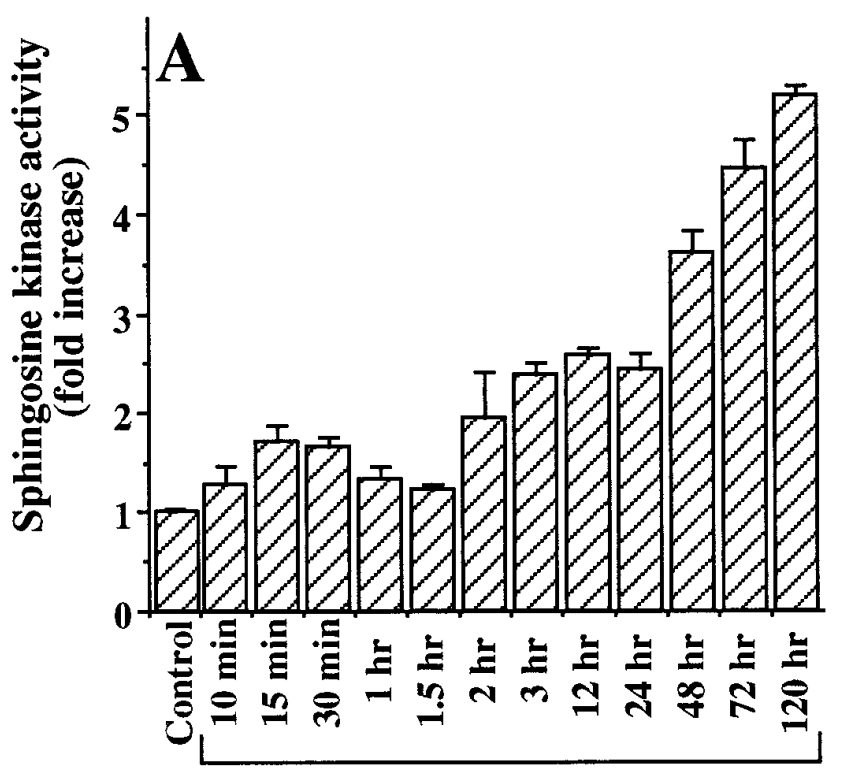

Time of NGF treatment

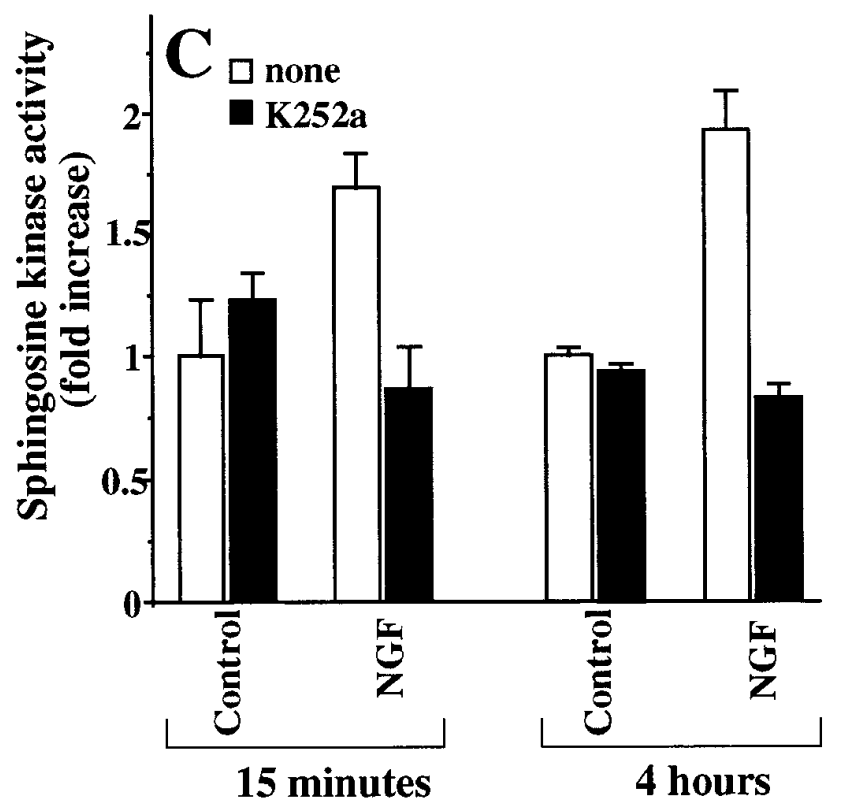

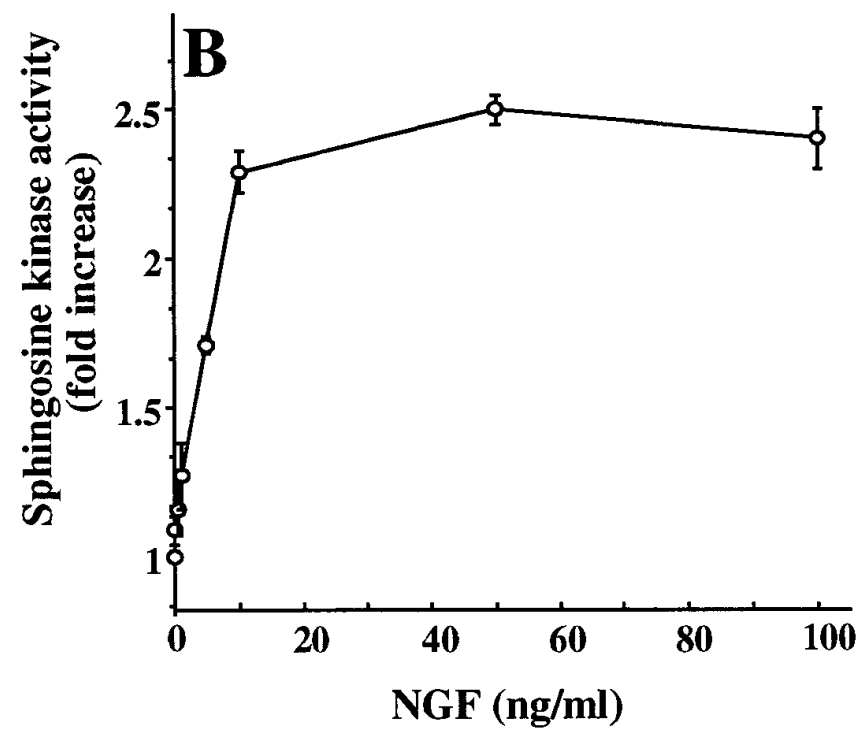

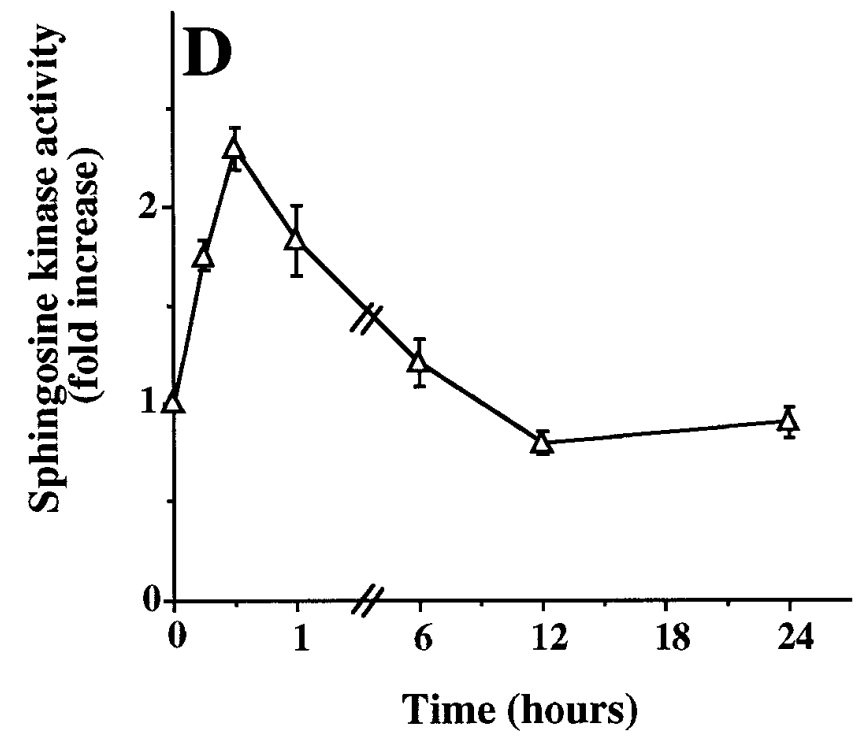

Figure 1. NGF stimulates sphingosine kinase in rat pheochromocytoma PC12 cells. $A$, Time course. PC12 cells were treated with NGF (100 ng/ml) for the indicated times, and cytosolic sphingosine kinase activity was measured as described in Materials and Methods. Data are the mean \pm SD of triplicate cultures expressed as fold increase over control values. Similar results were obtained in three independent experiments. $B$, Dose response. PC12 cells were treated with or without various concentrations of NGF for $24 \mathrm{hr}$, and cytosolic sphingosine kinase activity was measured. Data are the mean \pm SD of triplicate cultures expressed as fold increase over control values. $C$, Inhibition by the trkA receptor inhibitor K252a. PC12 cells were treated with NGF $(100 \mathrm{ng} / \mathrm{ml})$ in the absence (open bars) or presence (solid bars) of K252a (200 nM), and sphingosine kinase activity was measured after $15 \mathrm{~min}$ and $4 \mathrm{hr}$. Results are expressed as fold increase over control values and are the mean \pm SD of triplicate cultures. Similar results were obtained in three separate experiments. D, TPA stimulates sphingosine kinase activity. PC12 cells were treated with TPA (200 nM) for the indicated times, and sphingosine kinase activity was measured. Sphingosine kinase activity is expressed as fold increase over control values and is the mean \pm SD of triplicate cultures.

Neurofilament assay. PC12 cells were seeded onto collagen-coated plates, and after $24 \mathrm{hr}$, cells were washed two times with serum-free medium and then treated with the indicated agents. Cells were scraped in lysis buffer [20 mM HEPES, pH 7.2, $1 \%$ Nonidet P-40, 10\% (v/v) glycerol, $50 \mathrm{~mm} \mathrm{NaF}, 1 \mathrm{~mm}$ PMSF, $1 \mathrm{mM} \mathrm{Na}_{3} \mathrm{VO}_{4}$, and $10 \mu \mathrm{g} / \mathrm{ml}$ leupeptin]. Equal amounts of protein from the cell lysates were electrophoresed on a $7.5 \%$ SDS-polyacrylamide gel and subsequently transblotted to nitrocellulose $(0.45 \mu \mathrm{M})$. Membranes were probed with monoclonal anti-neurofilament, $\mathrm{M}$ and immunoreactive bands were detected by chemiluminescence using horseradish peroxidase-conjugated anti-mouse $\mathrm{IgG}$ and quantitated by densitometric analysis.

\section{RESULTS}

\section{NGF activates sphingosine kinase and increases SPP levels via the trkA receptor}

We previously reported that PDGF, but not epidermal growth factor, stimulated sphingosine kinase activity and increased SPP levels in Swiss 3 T3 fibroblasts (Olivera and Spiegel, 1993). It was of interest to examine whether NGF, a well known pleiotropic growth factor for PC12 cells, could also regulate levels of sphin- 

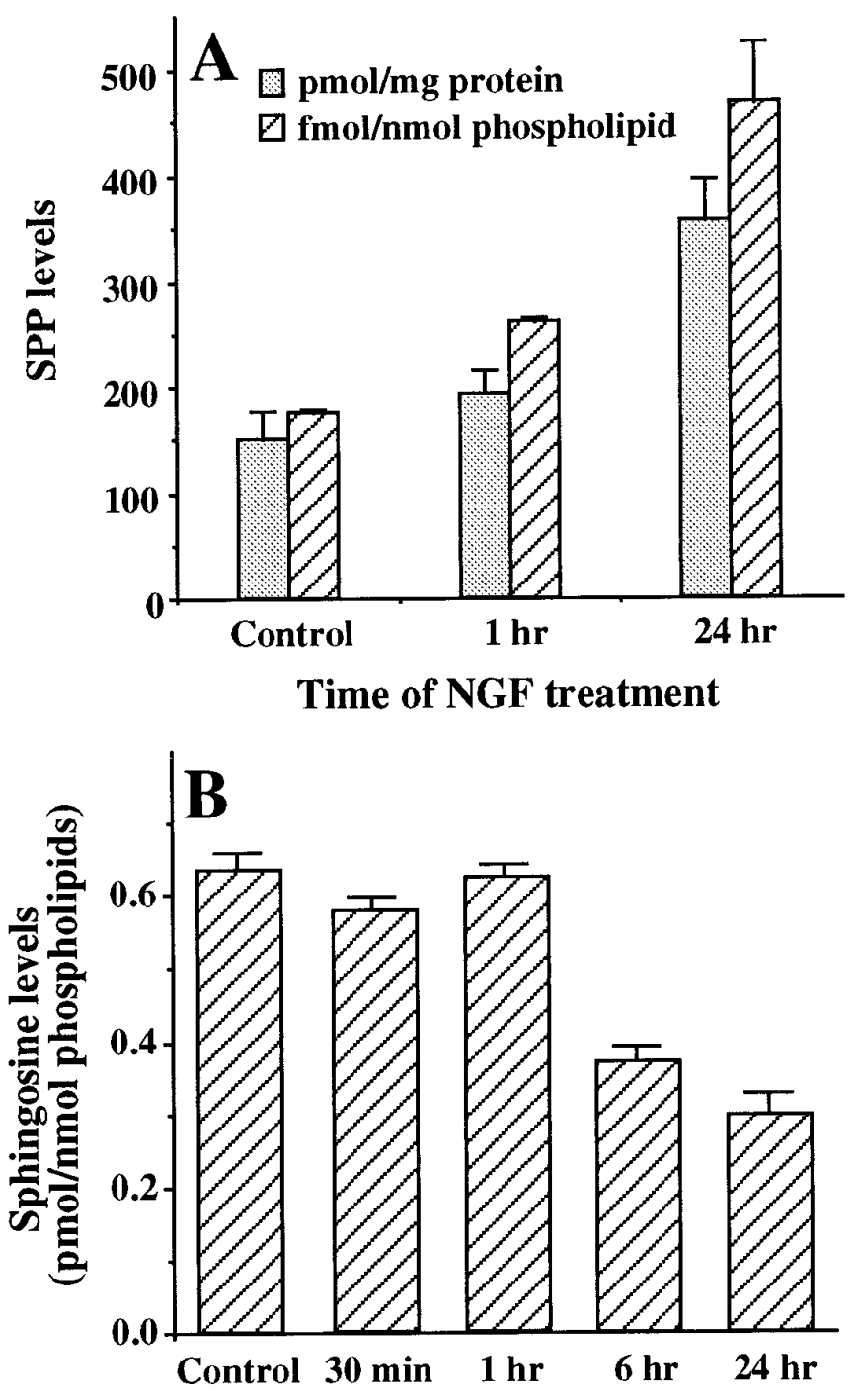

Time of NGF treatment

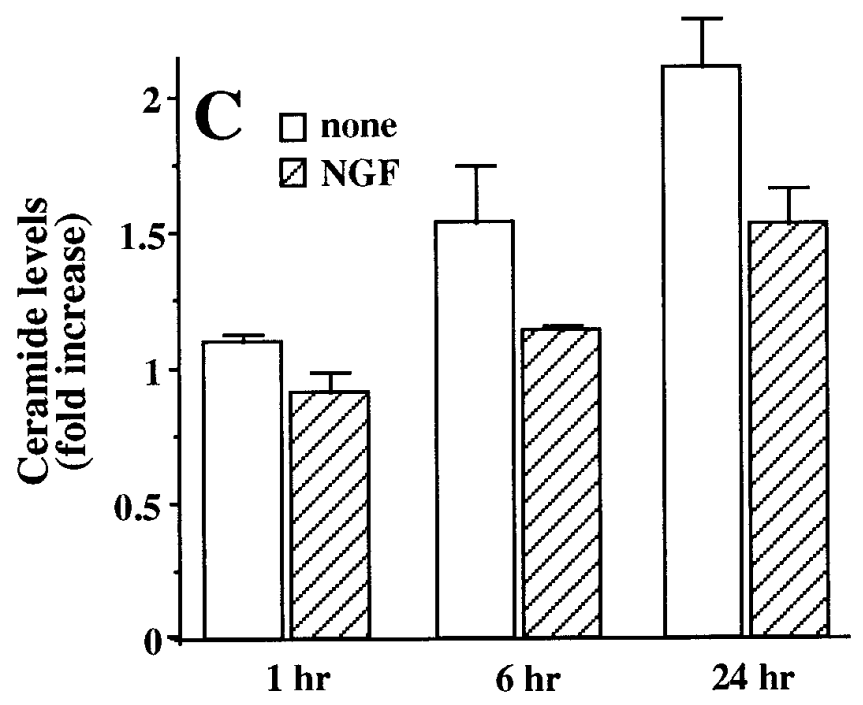

Time of serum free treatment
A

B
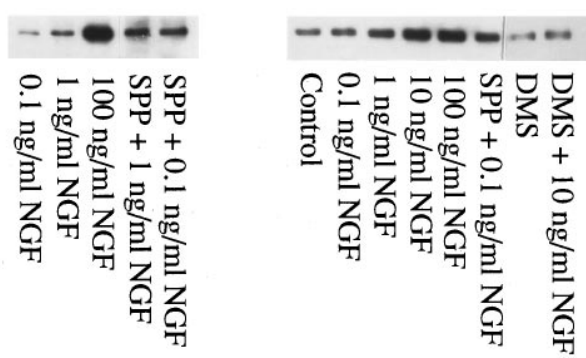

Figure 3. Involvement of SPP in NGF-induced expression of neurofilament protein. $A$, SPP enhances the effect of suboptimal concentrations of NGF on levels of neurofilament protein. After treatment with NGF $(0.1-100 \mathrm{ng} / \mathrm{ml})$, SPP $(10 \mu \mathrm{M})$, or a combination of SPP $(10 \mu \mathrm{M})$ and NGF $(0.1$ or $1 \mathrm{ng} / \mathrm{ml})$, neurofilament expression was determined as described in Materials and Methods. Twenty-five micrograms of total cellular protein was loaded in each lane of an SDS-PAGE gel. After transblotting to nitrocellulose, blots were probed with monoclonal anti-neurofilament $\mathrm{M}$ antibody. Results shown are from a representative experiment. Similar results were obtained in five independent experiments. $B, N, N$ Dimethylsphingosine $(D M S)$, an inhibitor of sphingosine kinase, inhibits neurofilament expression induced by NGF. PC12 cells were treated with the indicated concentrations NGF in the absence or presence of $\mathrm{N}, \mathrm{N}$ dimethylsphingosine $(10 \mu \mathrm{M})$, and neurofilament levels were analyzed by Western blotting. Similar results were obtained in four independent experiments.

golipid metabolites. Treatment of PC12 cells with NGF markedly stimulated sphingosine kinase activity. A rapid $75 \%$ increase in kinase activity was observed within 15 min that was then followed by a gradual and prolonged elevation of fourfold to fivefold by 72 hr (Fig. 1A). Similar results were obtained in the absence or presence of serum. After treatment for $24 \mathrm{hr}$, significant activation of sphingosine kinase was observed at a concentration of $\mathrm{NGF}$ as low as $1 \mathrm{ng} / \mathrm{ml}$, with maximum stimulation plateauing at a concentration of $10 \mathrm{ng} / \mathrm{ml}$ (Fig. $1 B$ ). Because most of the actions of NGF are known to be mediated by binding to the trkA receptor (Greene and Kaplan, 1995), we investigated whether trkA function was required for activation of sphingosine kinase by NGF. K252a, a relatively specific inhibitor of trkA (Berg et al., 1992), completely blocked both phases of activation of sphingosine kinase induced by NGF (Fig. 1C), indicating that the trkA receptor is essential for NGF-induced sphingosine kinase activa-

Figure 2. NGF induces changes in levels of sphingolipid metabolites. $A$, Mass levels of SPP. PC12 cells were treated with NGF $(100 \mathrm{ng} / \mathrm{ml})$ for the indicated times, and SPP was quantified as described in Materials and Methods. SPP levels are expressed as picomoles per milligram of protein (dotted bars) and as femtomoles per nanomoles of phospholipid (hatched bars) and are the mean \pm SD of triplicate cultures. $B$, Sphingosine levels. After treatment with NGF $(100 \mathrm{ng} / \mathrm{ml})$ for the indicated times, cellular lipids were extracted, and sphingosine levels were measured by HPLC as described in Materials and Methods. Sphingosine levels are expressed as picomoles normalized to total phospholipids and are the mean \pm SD of triplicate cultures. $C$, Ceramide levels. PC12 cells were cultured in serumfree medium in the absence (open bars) or presence (hatched bars) of NGF $(100 \mathrm{ng} / \mathrm{ml})$ for the indicated times. Ceramide levels were determined as described in Materials and Methods. For controls, ceramide levels were determined in untreated PC12 cells cultured in serum-containing medium for $24 \mathrm{hr}$ and were found to be $5.3 \pm 0.2 \mathrm{pmol} / \mathrm{nmol}$ of phospholipids. Ceramide levels were normalized to total phospholipids and are expressed as the mean \pm SD of fold increases over control values. Similar results were obtained in three independent experiments. 

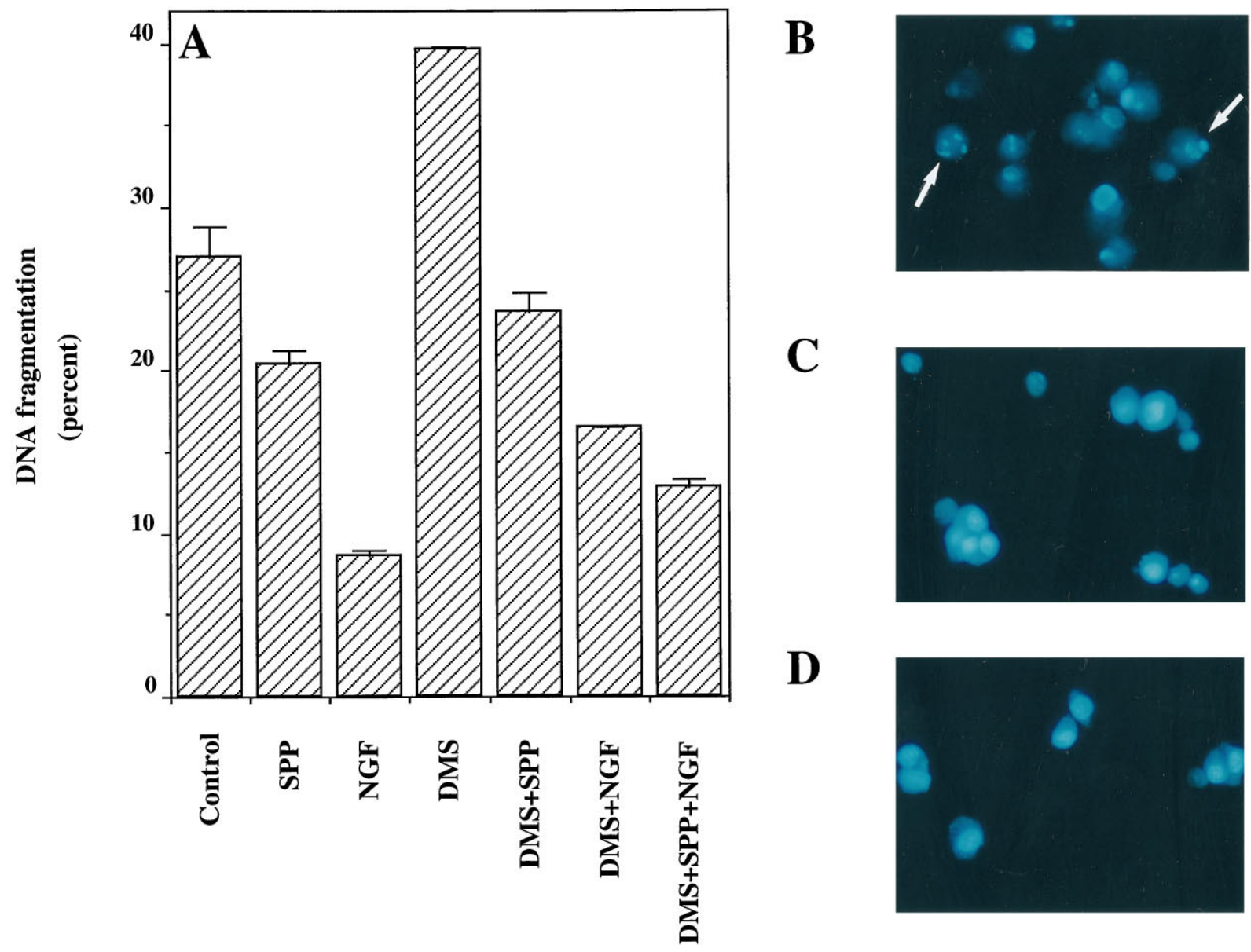

Control

$\mathbf{C}$

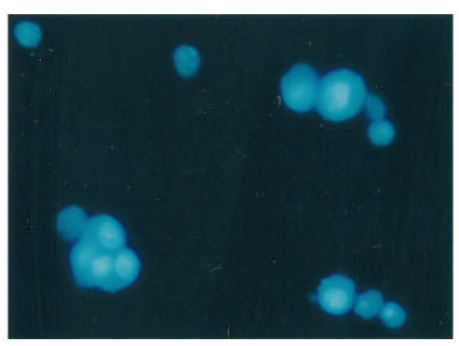

SPP

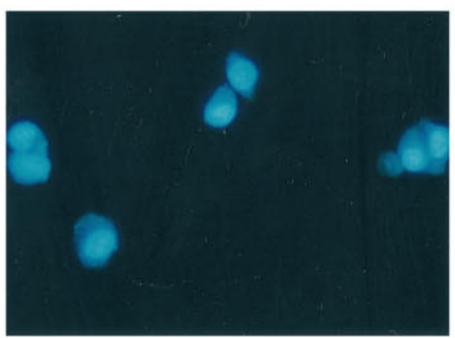

Figure 4. Effects of SPP and $N, N$-dimethylsphingosine on apoptosis in PC12 cells. $A, \mathrm{PC} 12$ cells were prelabeled with [ $\left.{ }^{3} \mathrm{H}\right]$ thymidine and then treated in serum-free medium for $4 \mathrm{hr}$ without or with NGF $(100 \mathrm{ng} / \mathrm{ml})$, SPP $(5 \mu \mathrm{M})$, dimethylsphingosine $(D M S, 10 \mu \mathrm{M})$, or the indicated combinations, and DNA fragmentation was determined. Data are expressed as percent DNA fragmentation and are the mean \pm SD of triplicate cultures. Similar results were obtained in three independent experiments. PC12 cells were incubated for $24 \mathrm{hr}$ in serum-free medium without $(B)$ or with $5 \mu \mathrm{M}$ SPP $(C)$ or 100 $\mathrm{ng} / \mathrm{ml}$ NGF $(D)$ and then stained with the DNA-specific fluorochrome bisbenzimide.

tion. In many cell types, activation of protein kinase $\mathrm{C}$ (PKC) by the phorbol ester TPA results in stimulation of sphingosine kinase activity (Mazurek et al., 1994; Spiegel and Milstien, 1995; Cuvillier et al., 1996). In agreement, TPA transiently stimulated sphingosine kinase activity in PC12 cells (Fig. 1D). However, in contrast to the prolonged activation of sphingosine kinase induced by NGF, the effects of TPA rapidly diminished after $1 \mathrm{hr}$, and further treatment with TPA did not have any significant effects, probably because of downregulation of PKC.

Activation of sphingosine kinase by NGF was accompanied by an increase in cellular levels of SPP (Fig. $2 A$ ). A small but significant increase was observed after $1 \mathrm{hr}$, which increased to 2.5-fold after $24 \mathrm{hr}$ treatment with NGF in the presence of serum. Treatment with NGF for up to $1 \mathrm{hr}$ had no significant effect on sphingosine levels as measured by HPLC (Wilson et al., 1988). However, after 6 and $24 \mathrm{hr}$, there were small but significant decreases in sphingosine (Fig. $2 B$ ), approximately corresponding to the mass increase in SPP after NGF treatment. Identical results were found when levels of sphingosine were measured by the enzymatic assay method recently described by our laboratory (Olivera et al., 1994). It should be noted that the ratio of sphingosine to sphinganine (dihydrosphingosine) is $\sim 20: 1$, and the levels of dihydrosphingosine-1-phosphate in PC12 cells were below our detection limits. Levels of ceramide, the precursor of sphingosine, which are 10- to 20-fold greater than sphingosine or SPP levels in PC12 cells, decreased $\sim 23 \%$ after NGF treatment for $24 \mathrm{hr}$ in serum-containing medium. In agreement with previous studies (Jayadev et al., 1995; Hannun, 1996), serum deprivation induced a significant increase in ceramide levels (Fig. 2C). Interestingly, NGF decreased the elevation of ceramide induced by serum withdrawal (Fig. 2C).

\section{Effect of SPP on NGF-induced neuritogenesis}

NGF induces neuritogenesis and enhances the survival of PC12 cells (Greene, 1978; Kaplan and Stephens, 1994). Because NGF markedly stimulates sphingosine kinase activity, leading to an increase in SPP levels, it was important to determine whether SPP plays a role in the pleiotropic effects of NGF. NGF induced dose-dependent expression of neurofilament, a protein exclusively found in neuronal cells (Tsuneishi et al., 1993), the expression of which correlates with neurite outgrowth. SPP alone did not significantly induce neurite outgrowth, nor did it increase neurofilament expression (data not shown). However, SPP enhanced the ability of suboptimal concentrations of NGF to induce neurofilament protein expression (Fig. $3 A$ ). To examine the possible role of endogenous SPP in the actions of NGF, we used $N, N$-dimethylsphingosine, a potent inhibitor of sphingosine kinase (Cuvillier et al., 1996). 


\begin{tabular}{|c|c|}
\hline Treatment & Apoptotic cells $(\%)$ \\
\hline None & $73.5 \pm 0.9$ \\
\hline SPP & $53.9 \pm 1.3$ \\
\hline NGF & $9.5 \pm 1.6$ \\
\hline DMS & $83.4 \pm 0.2$ \\
\hline $\mathrm{DMS}+\mathrm{NGF}$ & $18.5 \pm 1.9$ \\
\hline $\mathrm{DMS}+\mathrm{SPP}$ & $52.6 \pm 0.9$ \\
\hline $\mathrm{DMS}+\mathrm{NGF}+\mathrm{SPP}$ & $10.5 \pm 1.0$ \\
\hline
\end{tabular}

PC12 cells were incubated for $24 \mathrm{hr}$ in serum-free medium in the absence or presence of NGF $(100 \mathrm{ng} / \mathrm{ml})$, SPP $(5 \mu \mathrm{M}), N, N$-dimethylsphingosine (DMS, $10 \mu \mathrm{M})$, or the indicated combinations. Changes of nuclear morphology characteristic of apoptosis were quantified after staining with the DNA-specific fluorochrome bisbenzimide. Cells with chromatin condensation or segmentation of nuclei into three or more fragmentations were considered apoptotic. At a minimum, 500 cells in each field were scored. The data represent two independent determinations from three separate experiments.

$N, N$-Dimethylsphingosine not only inhibited NGF-induced neurite outgrowth, it markedly reduced neurofilament expression in response to optimal concentrations of NGF (Fig. 3B), an effect that was partially reversed by the addition of SPP (data not shown). Because relatively high concentrations of $N, N$-dimethylsphingosine have also been shown to inhibit PKC activity (Khan et al., 1990), it was important to determine whether the inhibitory effects of $N, N$-dimethylsphingosine were attributable specifically to inhibition of sphingosine kinase. Treatment of PC12 cells with $N, N$-dimethylsphingosine, at concentrations that block the neurotrophic effects of NGF and inhibit sphingosine kinase activity and concomitant SPP formation, had no significant effect on TPA-induced activation of PKC (data not shown). Thus, the effect of $N, N$ dimethylsphingosine on differentiation does not appear to be mediated via inhibition of PKC.

\section{Effect of SPP on neuronal cell death}

In addition to promoting neuronal differentiation, NGF is essential for the survival of neurons in the central and peripheral nervous systems (Levi-Montalcini, 1987). We have recently shown that SPP can reverse apoptosis induced by TNF- $\alpha$, Fas ligation, and ceramide elevation, suggesting that the intracellular balance between levels of ceramide and SPP is a critical factor that determines the fate of cells (Cuvillier et al., 1996). Moreover, ceramide has been implicated in apoptosis induced by growth factor withdrawal (Hannun, 1996), and exogenous ceramide induces apoptosis in PC12 cells (Hartfield et al., 1997). In this study, we found that there was a significant increase in ceramide levels on removal of trophic support (Fig. $2 C$ ), which may contribute to the apoptotic response. In agreement with previous reports (Batistatou and Greene, 1991; Xia et al., 1995), serum deprivation induced apoptosis in PC12 cells within $4 \mathrm{hr}$, as determined by quantitative DNA fragmentation (Fig. $4 A$ ), and shrinkage of cell bodies and condensation of nuclei were clearly evident after $24 \mathrm{hr}$ (Fig. 4B). NGF eliminated DNA fragmentation and nuclei condensation and enhanced cell survival (Fig. 4A, Tables 1, 2). Exogenous SPP also prevented DNA fragmentation because of serum deprivation, albeit to a lesser extent than NGF (Fig. 4A). In addition, SPP partially prevented the appearance of nuclei with apoptotic features determined by staining with the DNA-specific fluorochrome bisbenzimide (Fig. 4C), whereas, as expected, NGF almost completely prevented the apoptotic response (Fig. 4D).
Table 2. SPP enhances short-term survival of PC12 cells in serum-free medium

\begin{tabular}{ll} 
Treatment & Surviving cells (\%) \\
\hline None & $52.2 \pm 1.2$ \\
SPP & $72.2 \pm 0.2$ \\
NGF & $90.9 \pm 1.0$ \\
DMS & $50.5 \pm 0.6$ \\
DMS + NGF & $59.8 \pm 1.3$ \\
DMS + SPP & $75.1 \pm 0.9$ \\
DMS + NGF + SPP & $85.5 \pm 1.2$
\end{tabular}

PC12 cells were incubated for $24 \mathrm{hr}$ in serum-free medium in the absence or presence of NGF (100 ng/ml), SPP (5 $\mu \mathrm{M}), N, N$-dimethylsphingosine (DMS, $10 \mu \mathrm{M})$, or the indicated combinations. After $24 \mathrm{hr}$ in culture, viable cells were quantified by determining the number of intact nuclei, as described in Materials and Methods. The numbers of surviving cells are presented relative to the number of cells initially plated $\left(12.5 \times 10^{4}\right.$, designated as $\left.100 \%\right)$. Comparable results were obtained in two separate experiments.

The protective effect of SPP was specific, because other structurally related lipid analogs, such as lysophosphatidic acid or dihydrosphingosine-1-phosphate, which lacks the trans double bond present in SPP, did not significantly prevent apoptosis resulting from serum withdrawal after $9 \mathrm{hr}$ (Fig. $5 A$ ) or $18 \mathrm{hr}$ (Fig. $5 B)$. Similar results were obtained using a quantitative DNA fragmentation assay (data not shown). To substantiate a role for endogenous SPP in the cytoprotective effect of NGF further, we again used the competitive inhibitor of sphingosine kinase, $N, N$ dimethylsphingosine. At a concentration that markedly inhibited sphingosine kinase activity and decreased SPP levels, $N, N$ dimethylsphingosine increased DNA fragmentation (Fig. 4A). Moreover, $N, N$-dimethylsphingosine also inhibited the antiapoptotic effect of NGF (Fig. $4 A$ ). If SPP is a critical component in the cytoprotective effect of NGF, as suggested by these results, then addition of SPP should overcome the effects of $N, N$ dimethylsphingosine. Indeed, SPP was able to reverse the effect of $N, N$-dimethylsphingosine on induced cell death effectively and also to restore the cytoprotective activity of NGF (Fig. 4A). Similar results were obtained with two additional independent assays of apoptosis. Quantitation of condensed, fragmented apoptotic nuclei (Table 1) as well as determination of cell survival (Table 2) showed that SPP exerted the same cytoprotective effects as found in the DNA fragmentation assays and also counteracted the effects of $N, N$-dimethylsphingosine.

\section{DISCUSSION}

NGF is generally considered to be important for survival and differentiation of neurons (Greene, 1978; Kaplan and Stephens, 1994; Xia et al., 1995). These effects are mainly mediated by binding of NGF to the high-affinity trkA tyrosine kinase receptor, which initiates several parallel signaling cascades, including activation of phospholipase $\mathrm{C} \gamma$, phosphatidylinositol-3 kinase, and the extracellular signal-regulated kinase (ERK) pathway (Greene and Kaplan, 1995). More recently, attention has also been focused on the low-affinity NGF receptor p $75^{\mathrm{NGFR}}$, which not only regulates trkA signaling and NGF binding affinity to trkA (Benedetti et al., 1993; Hantzopoulos et al., 1994; Verdi et al., 1994), but additionally is instrumental in engaging death pathways of NGF (Rabizadeh et al., 1993; Cassacia-Bonnefil et al., 1996; Frade et al., 1996; Van der Zee et al., 1996). Early in development, binding of NGF to p75 NGFR causes the elimination of excess retinal neurons of chick embryos, which do not contain trkA (Frade et al., 1996). Similarly, p75 NGFR mediates apoptosis in vivo of de- 

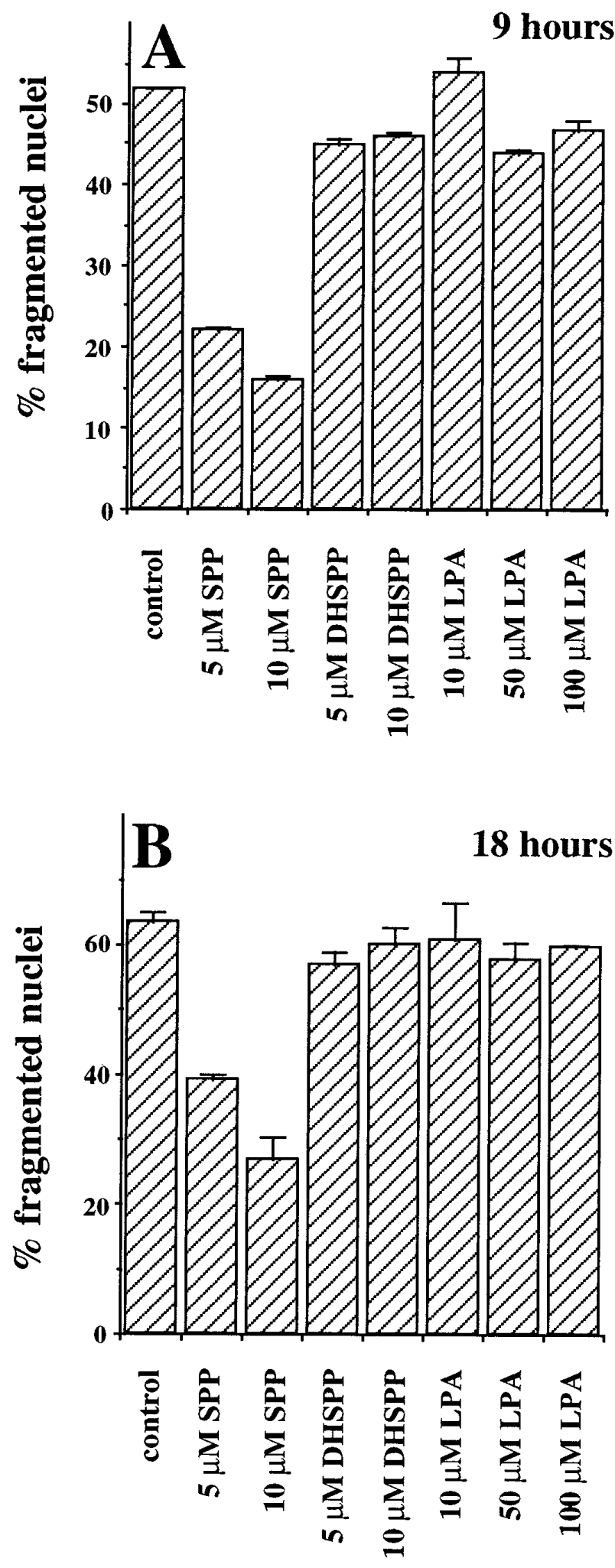

Figure 5. Effects of SPP analogs on apoptosis induced by trophic factor withdrawal. PC12 cells were incubated in serum-free medium in the absence or presence of the indicated concentrations of SPP dihydrosphingosine-1-phosphate (DHSPP) or lysophosphatidic acid $(L P A)$ for $9 \mathrm{hr}(A)$ or $18 \mathrm{hr}(B)$ and then stained with bisbenzimide. Cells with chromatin condensation or segmentation of nuclei into three or more fragmentations were considered apoptotic. At a minimum, 500 cells in each field were scored. Similar results were obtained in three independent experiments. veloping neostriatum and cholinergic forebrain neurons only in the absence of trkA (Van der Zee et al., 1996). Moreover, death of mature oligodendrocytes is mediated by interaction of NGF with p75 NGFR (Cassacia-Bonnefil et al., 1996). Although the mechanism by which $\mathrm{p} 75^{\mathrm{NGFR}}$ initiates the death cascade is not well understood, $\mathrm{p} 75^{\mathrm{NGFR}}$ displays structural similarity to the TNF family of receptors that initiate cell death in lymphocytes. Recently, it has been shown that NGF, similar to TNF- $\alpha$, activates the sphingomyelinase cycle through p $75^{\text {NGFR }}$ (Dobrowsky et al., 1995; Carter et al., 1996). Moreover, binding of NGF, but not BDNF or neurotrophin-3, to $\mathrm{p} 75^{\mathrm{NGFR}}$ in mature oligodendrocytes results in sustained increases in intracellular ceramide and c-Jun amino-terminal kinase (JNK) activity (CassaciaBonnefil et al., 1996). Interestingly, enhanced ceramide production was abolished in the presence of trkA, and inhibition of the tyrosine kinase activity of trkA with K252a restored the ability of NGF to induce sphingomyelin hydrolysis (Dobrowsky et al., 1995), suggesting that there may be crosstalk between these two NGF receptor-dependent signaling pathways.

In this study, we found that in PC12 cells NGF stimulated the formation of a further metabolite of ceramide, SPP, by markedly activating sphingosine kinase, the enzyme that catalyzes the phosphorylation of sphingosine to SPP. Pretreatment of PC12 cells with K252a blocked both the increase in sphingosine kinase activity and trkA tyrosine phosphorylation, suggesting that activation of sphingosine kinase by NGF is mediated by trkA. SPP has been previously implicated as a second messenger playing an important role in signaling pathways initiated by the PDGF receptor (Olivera and Spiegel, 1993; Spiegel and Milstien, 1995). We used two approaches to examine the potential role of SPP in the pleiotropic responses to NGF in PC12 cells. First, addition of exogenous SPP protected PC12 cells from apoptosis induced by serum withdrawal. Second, $N, N$-dimethylsphingosine, a competitive inhibitor of sphingosine kinase, not only induced apoptosis by itself, but reduced the cytoprotective effect of NGF, which could then be restored by readdition of SPP. Thus, it seems that activation of sphingosine kinase by binding of NGF to trkA and subsequent formation of SPP may play an important role in the survival effect of NGF. Elevation of ceramide induced by serum deprivation was also prevented by NGF treatment, suggesting that exposure of PC12 cells to NGF has a major impact on the intracellular ratio of ceramide to SPP.

SPP may also play an important role in neuronal differentiation. Although addition of SPP to PC12 cells did not induce neuritogenesis, it markedly enhanced neurofilament expression induced by NGF. It should be noted that the effects of exogenous SPP may be complex, because certain types of neuronal cells may possess cell surface receptors for SPP. In differentiated N1E-115 neuroblastoma cells, exogenous SPP induces $\rho$-dependent neurite retraction and soma rounding (Postma et al., 1996), although this effect was not observed in PC12 cells. In further support of a role for endogenous SPP in PC12 differentiation, we found that $N, N$-dimethylsphingosine inhibited NGF-induced differentiation. Although relatively high concentrations of $N, N$-dimethylsphingosine have been shown to also inhibit PKC activity (Khan et al., 1990), the concentrations used in this study markedly inhibit sphingosine kinase activity without having a significant effect on PKC. Previously, it has been shown that sphingosine can suppress NGF-directed neurite outgrowth in PC12 cells (Hall et al., 1988). This effect may be mediated by conversion of sphingosine to ceramide, because elevation of ceramide levels by 
treatment of PC12 cells with sphingomyelinase suppresses neurite outgrowth induced by NGF via a PKC-independent pathway (Tamura et al., 1994). Moreover, increased ceramide levels within distal neurites inhibit neurite outgrowth in cultured rat sympathetic neurons, suggesting that ceramide negatively regulates neurite growth (Posse de Chaves et al., 1997). In agreement, we observed that NGF decreases the elevation of ceramide induced by removal of trophic support. As an added complexity, in Neuro2A neuroblastoma cells, both sphingosine and ceramide stimulate differentiation (Riboni et al., 1995). Thus, the role of sphingolipid metabolites in neuronal differentiation may vary with different cell types.

Activations of three mitogen-activated protein kinases (MAPKs) present in distinct but related pathways play crucial roles in proliferation, differentiation, and survival of PC12 cells. The importance of trkA in NGF-stimulated extracellular signalregulated kinases ERK-1 and ERK-2 in the Ras cascade leading to proliferation and neuritogenesis has been well established (Marshall, 1995). Recent studies have implicated stress-activated protein kinases, also known as JNKs, as well as p38 as obligatory components of cell death pathways in PC12 cells (Xia et al., 1995; Park et al., 1996). NGF withdrawal from PC12 cells results in simultaneous activation of JNK and inhibition of ERK (Xia et al., 1995). Experiments with dominant-interfering or constitutively activated forms of various components of the MAPK pathway demonstrate that activation of JNK and concurrent inhibition of ERK are critical for promotion of cell death in PC12 cells, and conversely, activation of ERK signals and suppression of JNK leads to the promotion of cell survival (Xia et al., 1995). It has been proposed that survival and death of PC12 cells may be determined by the dynamic balance between ERK and JNK and p38 signaling (Xia et al., 1995). Previously, it has been shown that transient activation of ERK stimulates cell growth, and prolonged activation results in differentiation (Marshall, 1995). In a similar manner, the duration of JNK activation may also be a crucial factor in mediating the signaling decision. Transient JNK induction leads to cellular proliferation, whereas sustained activation results in apoptosis (Chen et al., 1996). Therefore, a single kinase-signaling pathway may have distinct functions depending on the induction pattern in the context of other signaling pathways. It is important to note that ceramide and SPP have opposing effects on these pathways. Ceramide induces activation of JNK in many cell types, including HepG2 cells (Kyriakis et al., 1994), HL-60 cells (Westwick et al., 1995), rat glomerular mesangial cells (Coroneos et al., 1996), airway smooth muscle cells (Pyne et al., 1996), and U937 monoblastic leukemia cells (Cuvillier et al., 1996). Dominant-negative $N$-terminal deletion mutants of c-Jun and dominant-negative mutants of MEK4, the kinase that phosphorylates and activates JNK, block ceramide-mediated apoptosis (Verheij et al., 1996). However, SPP, in contrast to ceramide, not only stimulates ERK-1 and ERK-2 in many cell types, such as Swiss 3 T3 fibroblasts, airway smooth muscle cells, HL-60 human promyelocytic cells, and U937 cells (Wu et al., 1995; Cuvillier et al., 1996; Pyne et al., 1996), it also inhibits JNK activity stimulated by TNF- $\alpha$ or ceramide (Cuvillier et al., 1996). Although growth factors can increase SPP levels, levels of ceramide are elevated during stress conditions (Cuvillier et al., 1996). Thus, the relative intracellular levels of ceramide and SPP and potential consequent activation or inhibition of distinct members of the MAPK cascades are important factors in determining the fate of cells (Cuvillier et al., 1996). This study suggests that such reciprocal situations may also be important for NGF action. As similarly speculated by Posse de Chaves et al. (1997), when growth arrest and neurite retraction are required, it is anticipated that trkA functions would be inhibited, and engagement of p $75^{\text {NGFR }}$ would activate sphingomyelinase activity, leading to increased ceramide levels, and conversely, when survival and neurite extensions are required, trkA would not only suppress the ability of $\mathrm{p} 75^{\mathrm{NGFR}}$ to stimulate sphingomyelinase, it would also stimulate sphingosine kinase and increase SPP levels. Thus, crosstalk between $\mathrm{p} 75^{\mathrm{NGFR}}$ and trkA may modulate the production of ceramide and SPP, affecting pathways involved in maintenance and differentiation of neuronal cells.

\section{REFERENCES}

Batistatou A, Greene L (1991) Aurintricarboxylic acid rescues PC12 cells and sympathetic neurons from cell death caused by nerve growth factor deprivation: correlation with suppression of endonuclease activity. J Cell Biol 115:461-471.

Benedetti M, Levi A, Chao M (1993) Differential expression of nerve growth factor receptors leads to altered binding affinity and neurotrophin responsiveness. Proc Natl Acad Sci USA 90:7859-7863.

Berg M, Sternberg D, Parada L, Chao M (1992) K252a inhibits nerve growth factor induced trk protooncogene tyrosine phosphorylation and kinase activity. J Biol Chem 267:13-16.

Bothwell M (1996) p75 ${ }^{\text {NTR: }}$ a receptor after all. Science 272:506-507.

Carter B, Kaltschmidt C, Kaltschmidt B, Offenhauser N, Bohm-Matthaei R, Baeuerle P, Barde Y (1996) Selective activation of NF $\kappa$ B by nerve growth factor through the neurotrophin receptor p75. Science 272:542-545.

Cassacia-Bonnefil P, Carter B, Dobrowsky R, Chao M (1996) Death of oligodendrocytes mediated by the interaction of nerve growth factor with its receptor p75. Nature 383:716-719.

Chen YR, Wang X, Templeton D, Davis RJ, Tan TH (1996) The role of c-Jun N-terminal kinase (JNK) in apoptosis induced by ultraviolet C and $\gamma$ radiation: duration of JNK activation may determine cell death and proliferation. J Biol Chem 271:31929-31936.

Coroneos E, Wang Y, Panuska JR, Templeton DJ, Kester M (1996) Sphingolipid metabolites differentially regulate extracellular signalregulated kinase and stress-activated protein kinase cascades. Biochem J 316:13-17.

Cuvillier O, Pirianov G, Kleuser B, Vanek P, Coso O, Gutkind J, Spiegel S (1996) Sphingosine 1-phosphate inhibits ceramide mediated programmed cell death. Nature 381:800-803.

Dobrowsky R, Werner M, Castellino A, Chao M, Hannun YA (1994) Activation of the sphingomyelin cycle through the low affinity neurotrophin receptor. Science 265:1596-1599.

Dobrowsky R, Jenkins G, Hannun YA (1995) Neurotrophins induce sphingomyelin hydrolysis. J Biol Chem 270:22135-22142.

Duke RC, Cohen JJ (1992) Morphological and biochemical assays of apoptosis. In: Current protocols in immunology, Suppl 3 (Coligan JE, Kruisbeek AM, Margulies DH, Shevach EM, Strober W, eds), pp 3.17.1-3.17.16. New York: Green/Wiley.

Frade JM, Rodriguez-Tebar A, Barde YA (1996) Induction of cell death by endogenous nerve growth factor through its p 75 receptor. Nature 383:166-168.

Greene L (1978) NGF prevents the death and stimulates neuronal differentiation of clonal PC12 pheochromocytoma cells in serum free medium. J Cell Biol 78:747-755.

Greene L, Kaplan D (1995) Early events in neurotrophin signaling via trk and p75 receptors. Curr Opin Neurobiol 5:579-587.

Hall FL, Fernyhough P, Ishii DN, Vulliet PR (1988) Suppression of nerve growth factor-directed neurite outgrowth in PC12 cells by sphingosine, an inhibitor of protein kinase C. J Biol Chem 263:4460-4466.

Hannun YA (1994) The sphingomyelin cycle and the second messenger ceramide. J Biol Chem 269:3125-3128.

Hannun YA (1996) Functions of ceramide in coordinating cellular responses to stress. Science 274:1855-1859.

Hannun YA, Obeid L (1995) Ceramide: a stress signal and mediator of growth suppression and apoptosis. J Cell Biochem 58:191-198.

Hantzopoulos PA, Suri C, Glass DJ, Goldfarb MP, Yancopoulos GD (1994) The low affinity NGF receptor, p75, can collaborate with each of the trks to potentiate functional responses to the neurotrophins. Neuron 13:187-207. 
Hartfield P, Mayne G, Murray A (1997) Ceramide induces apoptosis in PC12 cells. FEBS Lett 401:148-152.

Jayadev S, Liu B, Bielawska A, Lee J, Nazaire F, Pushkareva M, Obeid L, Hannun Y (1995) Role for ceramide in cell cycle arrest. J Biol Chem 270:2047-2052.

Kaplan D, Stephens R (1994) Neurotrophin signal transduction by the trk receptor. J Neurobiol 25:1404-1417.

Khan W, Dobrowsky R, Touny S, Hannun Y (1990) Protein kinase C and platelet inhibition by D-erythro sphingosine: comparison with $N, N$ dimethylsphingosine and commercial preparation. Biochem Biophys Res Commun 172:683-691.

Kolesnick R, Golde DW (1994) The sphingomyelin pathway in tumor necrosis factor and interleukin-1 signaling. Cell 77:325-328.

Kyriakis JM, Banerjee P, Nikolakaki E, Dai T, Rubie EA, Ahmad MF, Avruch J, Woodgett JR (1994) The stress-activated protein kinase subfamily of c-Jun kinases. Nature 369:156-160.

Levi-Montalcini R (1987) The nerve growth factor 35 years later. Science 237:1154-1162.

Marshall C (1995) Specificity of receptor tyrosine kinase signaling: transient versus sustained extracellular signal-regulated kinase activation. Cell 80:179-185.

Mazurek N, Megidish T, Hakamori S, Igarashi Y (1994) Regulatory effect of phorbol esters on sphingosine kinase in BALB/C 3T3 fibroblasts (variant A31): demonstration of cell type-specific response-a preliminary note. Biochem Biophys Res Commun 198:1-9.

McDonald N, Chao M (1995) Structural determinants of neurotrophin action. J Biol Chem 270:19669-19672.

Olivera A, Spiegel S (1992) Sphingomyelinase and cell-permeable ceramide analogs stimulate cell proliferation in quiescent Swiss 3 T3 fibroblasts. J Biol Chem 267:26121-26127.

Olivera A, Spiegel S (1993) Sphingosine-1-phosphate as second messenger in cell proliferation induced by PDGF and FCS mitogens. Nature 365:557-560.

Olivera A, Rosenthal J, Spiegel S (1994) Sphingosine kinase from Swiss 3T3 fibroblasts: a convenient assay for the measurement of intracellular levels of free sphingoid bases. Anal Biochem 233:306-312.

Park DS, Stefanis L, Yan CYI, Farinelli SE, Greene LA (1996) Ordering the cell death pathway: differential effects of BCL2, an interleukin-1-converting enzyme family protease inhibitor, and other survival agents on JNK activation in serum/nerve growth factordeprived PC12 cells. J Biol Chem 271:21898-21905.

Posse de Chaves E, Bussiere M, Vance D, Campenot R, Vance J (1997) Elevation of ceramide within distal neurites inhibits neurite growth in cultured rat sympathetic neurons. J Biol Chem 272:3028-3035.

Postma F, Jalink K, Hengeveld T, Moolenaar W (1996) Sphingosine 1phosphate rapidly induces rho-dependent neurite retraction: action through a specific cell surface receptor. EMBO J 15:101-105.

Pyne S, Chapman J, Steele L, Pyne NJ (1996) Sphingomyelin-derived lipids differentially regulate the extracellular signal-regulated kinase 2 (ERK-2) and c-Jun N-terminal kinase (JNK) signal cascades in airway smooth muscle. Eur J Biochem 237:819-826.

Rabizadeh S, Oh D, Zhong LT, Yang J, Bitler CM, Butcher LL, Bredesen DE (1993) Induction of apoptosis by the low-affinity NGF receptor. Science 261:345-348.

Riboni L, Prinetti A, Bassi R, Caminiti A, Tettamanti G (1995) A mediator role of ceramide in the regulation of neuroblastoma Neuro2a cell differentiation. J Biol Chem 270:26868-26875.

Spiegel S, Milstien S (1995) Sphingolipid metabolites: members of a new class of lipid second messengers. J Membr Biol 146:225-237.

Tamura HO, Noto M, Kinoshita K, Ohkuma S, Ikezawa H (1994) Inhibition of NGF-induced neurite outgrowth of PC12 cells by Bacillus cereus sphingomyelinase, a bacterial hemolysin. Toxicon 32:629-633.

Tsuneishi S, Sano K, Nakamura H (1993) Serum depletion increases the neurofilament protein mRNA levels in a neuroblastoma cell line, GOTO. Mol Brain Res 17:119-128.

Van der Zee C, Ross G, Riopelle R, Hagg T (1996) Survival of cholinergic forebrain neurons in developing p $75^{\text {NGFR }}$ deficient mice. Science 274:1729-1732.

Van Veldhoven PP, Mannaerts GP (1987) Inorganic and organic phosphate measurements in the nanomolar range. Anal Biochem 161:45-48.

Verdi MM, Birren SJ, Ibanez CF, Persson H, Benedetti M, Chao M, Anderson DJ (1994) p75 ${ }^{\text {LNGFR }}$ regulates Trk signal transduction and NGF-induced neuronal differentiation in MAH cells. Neuron 12:733-745.

Verheij M, Bose R, Lin X, Yao B, Jarvis WD, Grant S, Birrer MJ, Szabo E, Zon LI, Kyriakis M, Haimovitz-Friedman A, Fuks Z, Kolesnick RN (1996) Requirement for ceramide-initiated SPK/JNK signaling in stress-induced apoptosis. Nature 380:75-79.

Westwick JK, Bielawska AE, Dbaibo G, Hannun YA, Brenner DA (1995) Ceramide activates the stress-activated protein kinases. J Biol Chem 270:22689-22692.

Wilson E, Wang E, Mullins RE, Uhlinger DJ, Liotta DC, Lambeth JD, Merril AH (1988) Modulation of the free sphingosine levels in human neutrophils by phorbol esters and other factors. J Biol Chem 263:9304-9309.

Wu J, Spiegel S, Sturgill TW (1995) Sphingosine-1-phosphate rapidly activates the MAP kinase pathway by a G-protein dependent mechanism. J Biol Chem 270:11484-11488.

Xia A, Dickens M, Raingeaud J, Davis RJ, Greenberg ME (1995) Opposing effects of ERK and JNK-p38 MAP kinases on apoptosis. Science 270:1326-1331.

Yatomi Y, Ruan F, Ohta H, Welch R, Hakamori S, Igarashi Y (1995) Quantitative measurement of sphingosine-1-phosphate in biological samples by acylation with radioactive acetic anhydride. Anal Biochem 230:315-320. 